\title{
SLAUGYTOJŲ SAVARANKIŠKUMAS, TEIKIANT BŪTINĄJĄ MEDICINOS PAGALBĄ
}

\author{
Dalẻ Smaidžiūnienė ${ }^{1}$, Agnẻ Mažeikytė ${ }^{2}$ Vytautas Kriščiūnas ${ }^{3}$ \\ ${ }^{1}$ Kauno kolegija, Medicinos fakultetas, \\ ${ }^{2}$ Ortopedijos technika, AB poliklinika Gijos klinikos, \\ ${ }^{3}$ Plungès rajono greitoji medicinos pagalba
}

Raktažodžiai: slaugytojų savarankiškumas, būtinoji medicinos pagalba.

\section{Santrauka}

Lietuvoje, kaip ir visame pasaulyje, slaugytojų atsakomybe ir kompetencija teikiant būtinają medicinos pagalbą nuolat didejja. Kartais slaugytojams tenka patiems priimti sprendimus dèl būtinosios medicinos pagalbos veiksmų, nes reikiamu metu nèra gydytojo. Skirtingoje darbo aplinkoje nesant gero mikroklimato, vadovų palaikymo, kartais žinių ar pasitikèjimo trūkumo, slaugytojų galimybės ūminių būklių metu savarankiškai priimti sprendimus labai sumažèja. Tyrimo tikslas - nustatyti slaugytojų savarankiškumą, teikiant būtinają medicinos pagalbą. Šiam tikslui ịgyvendinti atlikta anoniminè apklausa. Tyrime dalyvavo skubiosios pagalbos ir prièmimo skyrių bei greitosios medicinos pagalbos slaugytojai. Tyrimo metu atsiskleidè slaugytojų pasirengimas savarankiškai teikti būtinają pagalbą pagal Lietuvos medicinos normoje MN 28:2019 priskirtas kompetencijas. Labiausiai slaugytojai pasirengę savarankiškai skirti deguonį, teikti pagalbą traumų ir sužeidimų atvejais, vertinti pagrindines gyvybines funkcijas, išskyrus sąmonę pagal Glasgow komų skalę, atlikti pradinio gaivinimo veiksmus. Slaugytojai labiausiai nepasirengę savarankiškai spręsti esant karščiavimui dẻl sepsio. Daugiau nei dešimtadalis slaugytojų teigia negalintys savarankiškai dirbti su švirkštinèmis pompomis bei lašų dozatoriais. Iš tyrimo duomenų galima daryti prielaidą, kad didelè dalis slaugytojų gali savarankiškai skirti skausmo malšinanamuosius vaistus ibuprofeną ir paracetamoli, širdies bei kraujagyslių sistemą veikiantį medikamentą kaptoprili, kvėpavimo sistemą veikiantį inhaliatorių salbutamolị bei deguoni. Slaugytojai savo praktikoje nèra pasirengę savarankiškai skirti suksametonio chlorido ir nifedipino.

\section{Ivadas}

Dèl sparčios slaugos mokslo raidos ir didejjančio sveikatos paslaugų poreikio, slaugytojo darbas tampa vis reikšmingesnis visuomeneje. Šių dienų slaugytojai turi galimybę gauti gerą išsilavinimą, jų kompetencija yra nuolat tobulinama, itvirtinamos naujos veiklos ir funkcijos. Kartu iš slaugytojų reikalaujama vis daugiau: kritiškai mąstyti, priimti savarankiškus sprendimus, būti lyderiu ir prisiimti atsakomybę už savo veiksmus, dalyvauti atliekant slaugos mokslinius tyrimus [4]. Slaugytojas sveikatos priežiūros sistemoje privalo būti kompetentingas, rūpestingas, patikimas ir kvalifikuotas [1]. Iš slaugytojų sveikatos sistema reikalauja pastovaus teorinių žinių atnaujinimo, gerų praktinių igūdžių, savarankiškumo, atsakomybès už savo sprendimus ir jų iggyvendinimą [2].

Darbuotojo savarankiškumas yra galèjimas priimti sprendimus ir laisvė veikti pagal savo profesines žinias ir kompetenciją [6]. Būtinoji medicinos pagalba teikiama, kai žmogaus gyvybei gresia pavojus sutrikus kvejpavimo, kraujotakos, galvos smegenų veiklai, kai reikia gaivinti, kai pacientas yra patyręs traumą ir pan. [9].

Lietuvoje, kaip ir pasaulyje, nuolat didinama slaugytojų kompetencija ir atsakomybè. Anksčiau gaivinimo metu slaugytojų veiksmai buvo labiau riboti, šiandien slaugytojams patikimos vis sudètingesnès savarankiškos funkcijos: punktuoti veną, pradèti infuzoterapiją, užtikrinti kvėpavimo takų praeinamumą, skirti deguonies bei reikiamų medikamentų ir kt. [7]. P. Supametaporn (2013) išskiria asmeninius ir su darbu susijusius veiksnius, kurie turi įtakos slaugytojų profesiniam savarankiškumui [8]. Kokybiškai paciento priežiūrai reikalingas motyvuotas, kompetentingas personalas ir gera darbo aplinka, kuri sudarytų sąlygas užtikrinti tinkamą paciento priežiūrą. Geras mikroklimatas darbe padeda slaugytojams jaustis drąsiau, priimant jiems skirtus iššūkius bei panaudojant savo žinias. Slaugytojų kompetencija, vadovų 
palaikymas, yra vieni iš pagrindinių veiksnių, turinčių įtakos slaugytojų elgesiui darbe [5]. Tinkamos slaugytojų asmeninės savybès bei geras pasirengimas priimti greitus ir teisingus sprendimus, yra raktas ị paciento gyvybès išsaugojimą [2]. Veiksniai, mažinantys slaugytojų savarankiškumą priimant sprendimus, yra komandinio darbo ịgūdžių stoka ir perdèta slaugytojų kontrolè. Atlikti tyrimai parode, kad slaugytojai, kurie yra kontroliuojami, dažniau patiria stresą ir sunkiau geba tinkamai įvykdyti užduotis $[2 ; 3]$.

Tyrimo tikslas - nustatyti slaugytojų savarankiškumą, teikiant būtinają medicinos pagalbą.

\section{Tyrimo medžiaga ir metodai}

Siekiant nustatyti slaugytojų pasirengimą savarankiškai priimti sprendimus teikiant būtinają medicinos pagalbą, pasirinktas kiekybinis duomenų rinkimo metodas. Atlikta anoniminè slaugytojų apklausa. Duomenų analizei naudotas aprašomosios statistikos skaičiavimo metodas. Tyrimas buvo vykdomas internetinëje erdveje „Google forms“. Tyrimo imtis - atsitiktinè tikslinè. Tyrime dalyvavo 125 skubiosios pagalbos ir prièmimo bei greitosios medicinos pagalbos slaugytojai santykiu 29,6 ir 70,4 procento. Daugiau nei aštuoni dešimtadaliai tyrimo dalyviu buvo moterys. Didžiają dalị respondentų sudarè 25-35 metų slaugytojai.

1 lentelè. Slaugytojų gebėjimas savarankiškai atlikti gaivinimo veiksmus ir dirbti su medicinine įranga, proc.

\begin{tabular}{|l|c|c|c|}
\hline $\begin{array}{l}\text { Gaivinimo veiksmai ir darbas su medicinos } \\
\text { iranga }\end{array}$ & Sutinku & $\begin{array}{c}\text { Nei sutinku, } \\
\text { nei nesutinku }\end{array}$ & Nesutinku \\
\hline Pasiruošti ir atlikti defibriliaciją su (AID) & 93,6 & 4,0 & 2,4 \\
\hline $\begin{array}{l}\text { Atlikti pradinio gaivinimo veiksmus (paspau- } \\
\text { dimus, ịpūtimus) }\end{array}$ & 98,4 & 0,8 & 0,8 \\
\hline Išsiurbti kvėpavimo takų sekretą & 94,4 & 3,2 & 2,4 \\
\hline Taikyti deguonies terapiją & 98,4 & 0,0 & 1,6 \\
\hline $\begin{array}{l}\text { Atkurti kvėpavimo takų praeinamumą oro ir } \\
\text { (ar) nazofaringiniu vamzdeliu }\end{array}$ & 84,8 & 8,8 & 6,4 \\
\hline $\begin{array}{l}\text { Dirbti su švirkštinėmis pompomis ir lašų do- } \\
\text { zatoriais }\end{array}$ & 78,4 & 9,6 & 12,0 \\
\hline
\end{tabular}

2 lentelè. Slaugytojų gebėjimas savarankiškai skirti medikamentus gaivinimo metu, proc.

\begin{tabular}{|l|l|l|l|}
\hline Medikamentai gaivinimui & Sutinku & $\begin{array}{l}\text { Nei sutinku, } \\
\text { nei nesutinku }\end{array}$ & Nesutinku \\
\hline $\begin{array}{l}\text { Epinenefrinas (adrenalinas), } 1 \mathrm{mg} / \mathrm{ml} \text {, injekcinis } \\
\text { ar infuzinis tirpalas }\end{array}$ & 84,8 & 4,8 & 10,4 \\
\hline $\begin{array}{l}\text { Deguonis, 100\% suskystintosios, kriogeninès } \\
\text { ar suslègtosios medicininès dujos }\end{array}$ & 98,4 & 0,0 & 1,6 \\
\hline $\begin{array}{l}\text { Natrio chloridas, } 9 \mathrm{mg} / \mathrm{ml} \text { injekcinis ar infu- } \\
\text { zinis tirpalas }\end{array}$ & 96,0 & 0,8 & 3,2 \\
\hline
\end{tabular}

3 lentelè. Slaugytojų gebejjimas savarankiškai skirti kvėpavimo sistemą veikiančius medikamentus, esant ūminei būklei, proc.

\begin{tabular}{|l|c|c|c|}
\hline Medikamentai kvėpavimo valdymui & Sutinku & $\begin{array}{c}\text { Nei sutinku, } \\
\text { nei nesutinku }\end{array}$ & Nesutinku \\
\hline Aminofilinas, 24mg/ml, injekcinis ar infuzinis & 48,0 & 18,4 & 33,6 \\
\hline $\begin{array}{l}\text { Salbutamolis } 100 \mathrm{mg} \text {, dozejje suslègtoji ịkve- } \\
\text { piamoji suspensija }\end{array}$ & 89,6 & 2,4 & 8,0 \\
\hline
\end{tabular}

\section{Tyrimo rezultatai}

Atlikus literatūros analizę, buvo išskirti veiksmai, kurie galètų būti slaugytojų atliekami teikiant būtinąją medicinos pagalbą. Respondentams pateiktas klausimas apie savarankišką šių veiksmų atlikimą realiose būtinosios pagalbos teikimo situacijose. Pirmoji klausimų grupè buvo apie savarankišką gebėjimą atlikti tam tikrus gaivinimo veiksmus ir dirbti su medicinine įranga. Respondentų atsakymai pateikiami 1 lentelèje.

Daugiau nei devyni dešimtadaliai (93,6 proc.) tiriamujų nurodè, kad geba pasiruošti ir atlikti defibriliaciją automatiniu išoriniu defibriliatoriumi (AID). Beveik visi slaugytojai nurodẻ gebantys atlikti krūtinès ląstos paspaudimus ir dirbtinị kvépavimą $(98,4$ proc.), užtikrinti viršutinių kvėpavimo takų praeinamumą, išsiurbiant kvejpavimo takų sekretą (94,4 proc.) ir taikyti deguonies terapiją $(98,1$ proc.). Iš tyrimo rezultatu galima daryti prielaidą, kad slaugytojai labiausiai investuoja i gebejjimų tobulinimą atlikti pradinio gaivinimo veiksmus bei defibriliuoti. Tyrimas parodè, kad gebejimus atkurti kvėpavimo takų praeinamumą orofaringiniu ir nazofaringiniu vamzdeliu turi daugiau nei aštuoni dešimtadaliai (84,8 proc.) respondentų. Dirbti su lašų dozatoriais ir švirkštinèmis pompomis gali ne visi $(78,4$ proc.) slaugytojai. Tyrimas atskleide, kad didesnę kompetenciją šioje srityje turi prièmimo ir skubiosios pagalbos skyriuose dirbantys respondentai.

Respondentams buvo pateiktas klausimas apie savarankišką medikamentų skyrimą kardiopulmoninio gaivinimo metu. Atsakymai pateikiami 2 lentelëje.

Adrenaliną gaivinimo metu savarankiškai skiria daugiau nei aštuoni dešimtadaliai ( 84,8 proc.) slaugytojų ir tik dešimtadalis $(10,4$ proc.) pažymejjo, jog adrenalino nèra skyrę savarankiškai. Deguoni bei natrio chloridą 
savarankiškai skyrè daugiau nei devyni dešimtadaliai tiriamujų $(98,4$ ir 96,0 proc.).

Respondentams buvo pateiktas klausimas apie savarankišką kvėpavimo sistemą veikiančių medikamentu skyrimą ūminių būklių metu. Atsakymai pateikiami 3 lentelèje.

Nustatyta, kad savarankiškai skirti salbutamoli geba beveik devyni dešimtadaliai $(89,6$ proc.) respondentų ir beveik pusè ( 48,0 proc.) - aminofiliną.

Respondentams buvo užduotas klausimas apie temperatūrą ir skausmo malšinamujų medikamentų (ibuprofeno, paracetamolio, analgino, morfino) savarankišką skyrimą ūminių būklių metu. Atsakymai pateikiami 4 lentelèje.

Atsakymų rezultatai parodè, jog savarankiškai skirti ibuprofeną ir paracetamoli geba daugiau nei devyni dešimtadaliai tiriamujuc $(90,4$ proc.). Beveik dešimtadalis $(8,8$ proc.) respondentų pažymėjo, jog savarankiškai neskirtų ibuprofeno, o 8,0 proc. apklaustujų - paracetamolio. Analginą bei morfiną savarankiškai galètų skirti daugiau nei septyni dešimtadaliai respondentų ( 76,8 ir 79,2 proc.).

Vienas iš klausimų buvo apie savarankišką naloksono paskyrimą, esant apsinuodijimui opiatais. Daugiau kaip septyni dešimtadaliai ( 71,2 proc.) respondentų nurodè, kad ši medikamentą geba paskirti savarankiškai.

Esant traukuliams, ne visi slaugytojai gebètų suleisti diazepamo, tai padarytų tik daugiau nei aštuoni dešimtadaliai $(85,6$ proc.) apklaustujų.

Kita klausimų sritis buvo apie savarankišką širdies ir kraujagyslių sistemą veikiančių medikamentų (glicerolio trinitrato, kaptoprilio, nifedipino, adrenalino) skyrimą (5 lentelè).

Glicerolio trinitratą geba savarankiškai skirti daugiau nei aštuoni dešimtadaliai (84,8 proc.) respondentų. Kaptoprilị savarankiškai gali skirti beveik visi $(96,8$ proc.) tiriamieji, o nifedipiną tik daugiau nei pusė $(54,4$ proc.) respondentų.

MN 28:2019 nurodoma, kad teikiant būtinają medicinos pagalbą, slaugytojai gali paskirti hormoninių preparatų: deksametazono, prednizolono ir gliukagono. Respondentų pasisakymai apie gebejjimus savarankiškai skirti šiuos preparatus atsispindi 6 lentelèje.

Beveik devyni dešimtadaliai ( 88,8 proc.) slaugytojų teigia gebantys skirti

4 lentelè. Slaugytojų gebejjimas savarankiškai skirti nuskausminamuosius ir karščiavimą mažinančius medikamentus, esant ūminei būklei, proc.

\begin{tabular}{|l|c|c|c|}
\hline Medikamentai skausmui malšinti & Sutinku & $\begin{array}{c}\text { Nei sutinku, } \\
\text { nei nesutinku }\end{array}$ & Nesutinku \\
\hline Ibuprofenas, 400mg & 90,4 & 0,8 & 8,8 \\
\hline Paracetamolis, 500 mg & 90,4 & 1,6 & 8,0 \\
\hline $\begin{array}{l}\text { Metamizolo natrio druska (analginas), 1g/2ml, } \\
\text { injekcinis tirpalas }\end{array}$ & 76,8 & 4,0 & 19,2 \\
\hline $\begin{array}{l}\text { Morfinas, } 10 \mathrm{mg} / \mathrm{ml} \text {, injekcinis ar infuzinis } \\
\text { tirpalas }\end{array}$ & 79,2 & 4,8 & 16,0 \\
\hline
\end{tabular}

5 lentelė. Slaugytojų gebejjimas savarankiškai skirti širdies ir kraujagyslių sistemą veikiančius medikamentus, esant ūminei būklei, proc.

\begin{tabular}{|c|c|c|c|}
\hline Medikamentas & Sutinku & $\begin{array}{l}\text { Nei sutinku, } \\
\text { nei nesutinku }\end{array}$ & Nesutinku \\
\hline $\begin{array}{l}\text { Glicerolio trinitratas, } 500 \mu \mathrm{g} \text { poliežuvinès ta- } \\
\text { bletės }\end{array}$ & 84,8 & 4,0 & 11,2 \\
\hline Kaptoprilis, 25mg, tabletės & 96,8 & 0,8 & 2,4 \\
\hline $\begin{array}{l}\text { Nifedipinas, } 20 \mathrm{mg} \text {, pailginto atpalaidavimo } \\
\text { tabletès }\end{array}$ & 54,4 & 10,4 & 35,2 \\
\hline
\end{tabular}

6 lentelè. Slaugytojų gebèjimas savarankiškai skirti hormoninius preparatus esant ūminei būklei, proc.

\begin{tabular}{|l|c|c|c|}
\hline Medikamentas & Sutinku & $\begin{array}{c}\text { Nei sutinku, } \\
\text { nei nesutinku }\end{array}$ & Nesutinku \\
\hline $\begin{array}{l}\text { Deksametazonas, 4mg/ml, injekcinis ar infu- } \\
\text { zinis tirpalas }\end{array}$ & 88,8 & 0,8 & 10,4 \\
\hline $\begin{array}{l}\text { Gliukagonas, 1mg milteliai ir tirpiklis injek- } \\
\text { ciniam tirpalui }\end{array}$ & 63,2 & 8,8 & 28,0 \\
\hline $\begin{array}{l}\text { Metilprednizolonas, 40 mg, milteliai ir tirpiklis } \\
\text { injekciniam tirpalui }\end{array}$ & 49,6 & 10,4 & 40,0 \\
\hline
\end{tabular}

7 lentelè. Slaugytojų gebẻjimas savarankiškai vertinti paciento būklę ir gliukozės kiekio kraujyje rodmenis, proc.

\begin{tabular}{|l|l|l|l|}
\hline $\begin{array}{l}\text { Matavimo, skaičiavimo ir vertinimo veiks- } \\
\text { mai }\end{array}$ & Sutinku & $\begin{array}{l}\text { Nei sutinku, } \\
\text { nei nesutinku }\end{array}$ & Nesutinku \\
\hline Matuoti ir vertinti kūno temperatūrą & 99,2 & 0,0 & 0,8 \\
\hline Matuoti ir vertinti arterinị kraujospūdị (AKS) & 100,0 & 0,0 & 0,0 \\
\hline Skaičiuoti ir vertinti pulsą, kvėpavimo dažnį & 99,2 & 0,0 & 0,8 \\
\hline $\begin{array}{l}\text { Vertinti paciento sąmonę pagal Glasgow komų } \\
\text { skalę }\end{array}$ & 84,0 & 12,0 & 4,0 \\
\hline $\begin{array}{l}\text { Nustatyti skausmo intensyvumą, naudojant } \\
\text { skausmo skales }\end{array}$ & 94,4 & 4,0 & 1,6 \\
\hline Užrašyti ir vertinti elektrokardiogramą (EKG) & 92,8 & 5,6 & 1,6 \\
\hline $\begin{array}{l}\text { Matuoti ir vertinti gliukozės kiekị kapiliari- } \\
\text { niame kraujyje }\end{array}$ & 98,4 & 0,8 & 0,8 \\
\hline
\end{tabular}


deksametazoną, tačiau tik kone pusè (49,6 proc.) - prednizoloną. Gliukagono negeba skirti beveik trys dešimtadaliai respondentų, nors šis vaistas naudojamas esant hipoglikeminei komai.

Esant stipriam pykinimui, slaugytojų kompetencija leidžia skirti metoklopramidą ( $10 \mathrm{mg} / 2 \mathrm{ml}$ injekcinị tirpalą). Tyrimas atskleide, kad ji savarankiškai gebėtų paskirti truputi daugiau nei aštuoni dešimtadaliai ( 81,6 proc.) slaugytojų.

Gliukozè ( 5 proc.) ūminių būklių metu galètų būti panaudota amiodarono skiedimui gaivinant pacientą ar kaip paciento būklès stabilizavimui skirtas tirpalas, esant hipoglikemijai po cukraus ir (arba) gliukagono panaudojimo. Nèra visiškai aišku, kodèl ị MN 28:2019 buvo įtraukta tik 5 proc. gliukozè, o neįtraukta 40 proc. gliukozè, kuri praktikoje naudojama norint greitai atkurti cukraus kiekį kraujyje. Tyrimas parodé, kad savarankiškai panaudoti 5 proc. gliukozès tirpalą ūmių būklių metu gebètų aštuoni dešimtadaliai $(80,8$ proc.) slaugytoju..Apibendrinant galima teigti, kad skubiosios pagalbos ir prièmimo skyrių bei greitosios medicinos pagalbos slaugytojai, teikiantys būtinają medicinos pagalbą, yra nepakankamai pasirengę savarankiškai skirti medikamentus pagal MN 28:2019 priede patvirtintą medikamentų sąrašą., Medikamentų sąrašas turètų būti peržiūrètas. Slaugytojų praktikų nuomone, kai kurių jame esančių medikamentų neturètų būti, o kai kurie turètų būti ịtraukti, nes slaugytojai juos naudoja praktiškai.

Respondentų klausta apie gebejjimus savarankiškai atlikti paciento būklès ir gliukozès kiekio kraujyje vertinimo veiksmus, teikiant būtinają medicinos pagalbą. Atsakymai pateikiami 7 lentelèje.

Beveik visi slaugytojai (daugiau nei 98,0 proc.) nurodé, jog savarankiškai geba matuoti ir vertinti kūno temperatūrą, arterinị kraujospūdị (AKS), pulsą, kvẻpavimo dažnį. Vertinti paciento sąmonę pagal Glasgow komų skalę geba daugiau nei aštuoni dešimtadaliai tiriamujjų ( 84,0 proc.), nustatyti skausmo intensyvumą naudojant skausmo skales, užrašyti ir ịvertinti elektrokardiogramą (EKG), ar joje neužregistruota gyvybei pavojingų ūmiai atsiradusių ritmo sutrikimų, savarankiškai gali daugiau nei devyni dešimtadaliai respondentu (94,4 proc. ir 92,8 proc.).

Siekiant išsiaiškinti slaugytojų gebejimus savarankiškai teikti būtinają medicinos pagalbą traumų atvejais, respondentų buvo paklausta apie jų savarankiškumą tokiais atvejais. Visus reikiamus atlikti veiksmus: keisti paciento kūno padètị esant traumų, sužeidimų, uždèti šilumos arba šalčio aplikacijas, stabdyti išorinị kraujavimą, tvarstyti žaizdas, dèti imobilizacinius įtvarus daugiau nei devyni dešimtadaliai slaugytojų nurodo gebantys.

Vienas iš klausimų buvo apie respondentų savarankiškumą, atliekant tam tikras manipuliacijas, kurios dažniausiai reikalingos teikiant būtinają medicinos pagalbą. Tokias manipuliacijas, kaip gliukozès kiekio matavimas ir vertinimas, kraujo mėginių paėmimas iš piršto (venos) savarankiškai geba atlikti daugiau nei devyni dešimtadaliai respondentų (96,8 ir 92,0 proc.). Kateterizuoti šlapimo pūslę savarankišskai gali aštuoni dešimtadaliai ( 80,0 proc.) slaugytojų. Savarankiškai punktuoti veną ir ịkišti periferinį venos kateterị geba daugiau nei devyni dešimtadaliai slaugytojų. Zonduoti ir plauti skrandi savarankiškai geba daugiau nei aštuoni dešimtadaliai $(86,4$ proc.) respondentų.

\section{Išvados}

1. Slaugytojas yra teisètas pareigų vykdytojas, kuris pagal savo kompetenciją gali priimti savarankiškus sprendimus. Teikdamas būtinają pagalbą, slaugytojas vadovaujasi Lietuvos Respublikos teisès aktais, medicininiais norminiais dokumentais bei moralinėmis vertybėmis. Savarankiškam sprendimo prièmimui įtakos turi slaugytojų profesinè patirtis, charakteris, darbo aplinka, santykiai su kolegomis bei vadovavimo medicinos įstaigoms, kuriose jie dirba, stilius.

2. İvertinus slaugytojų savarankiškumą būtinosios pagalbos metu, nustatyta, kad slaugytojai puikiai geba priimti sprendimus ir savarankiškai vertinti pagrindines gyvybines funkcijas (išskyrus sąmonę pagal Glasgow komų skalę), gaivinti pacientus traumų atvejais, esant epilepsijos priepuoliui, matuoti bei vertinti gliukozės kiekị kraujyje, punktuoti veną ir ịstumti periferinès venos kateterį. Tyrimas parodè, kad ne visi slaugytojai geba atkurti kvépavimo takų praeinamumą orofaringiniu ir nazofaringiniu vamzdeliu.

3. Iš tyrimo duomenų galime daryti prielaidą, kad slaugytojai ne visuomet gali savarankiškai skirti medikamentus. Jie neturi gebejjimų paskirti suksametonio chlorido, sunkiau sekasi savarankiškai paskirti midazolamo, naloksono, aminofilino analgino, morfino, nifedipino, drotaverino, haloperidolio, metilprednizolono gliukagono. Slaugytojai savarankiškai puikiai geba skirti deguonies, skausmo malšinamujų vaistų, tokių kaip ibuprofenas ir paracetamolis, AKS mažinantį medikamentą kaptoprilį, kvejpavimo sistemą veikiantị inhaliatorių salbutamoli.

\section{Literatūra}

1. Aston L. The Student Nurse Guide to Decision Making in Practice. McGraw-Hill Education. 2010. www.ebsco.com

2. Farčić N, Barać I, Plužarić J, Ilakovac V, Pačarić S, Gvozdanović Z, Lovrić R. Personality traits of core self-evaluation as predictors on clinical decision-making in nursing profession. PLoS One 2020;15(5): e0233435.

https://doi.org/10.1371/journal.pone.0233435

3. Gerberich S. Risk Factors for Work-Related Assaults on Nurses. Epidemiology 2020;16(5):704-709. http://www.jstor.org/ 
stable/20486127

https://doi.org/10.1097/01.ede.0000164556.14509.a3

4. Greater leadership, autonomy and flexibility predicted for nurse of the future: Nursing Standard 2016;31(2):8. https://doi.org/10.7748/ns.31.2.8.s4

5. Kieft RA, de Brouwer BB, Francke AL, Delnoij DM. How nurses and their work environment affect patient experiences of the quality of care: a qualitative study. BMC Health Serv Res 2014;14(249).

https://doi.org/10.1186/1472-6963-14-249

6. Oshodi T. Registered nurses' perceptions and experiences of autonomy: a descriptive phenomenological study. BMC Nursing. 2019;51(18).

https://doi.org/10.1186/s12912-019-0378-3

7. Smaidžiūnienė, D., Gečaite, L. Savarankiškos slaugytojų veiklos igyvendinimas, gaivinant pacientą ligoninejje. Sveikatos mokslai, 2020;30(6).

https://doi.org/10.35988/sm-hs.2020.159

8. Supametaporn P. The Conceptualization of Professional Nurse Autonomy. Japan J Nurs Sci 2013;31(1):80-6.

https://he02.tci-thaijo.org/index.php/ns/article/view/10555

9. Vaitkaitis D., Pranckūnas A. (sudarytojai). Pirmoji medicinos pagalba. Krizių tyrimo centras 2017:23-24.

\section{INDEPENDENCE OF NURSES WHEN PROVIDING EMERGENCY MEDICAL CARE}

D. Smaidžiūnienė, A. Mažeikytė, V. Kriščiūnas

Keywords: independence of nurses, emergency medical care.
Summary

In Lithuania, same as in the whole world, nurses' responsibility and competence when providing emergency medical care are increasing, for this reason, it is necessary to evaluate nurses ' prepration to make decisions independently in order to see if nurses are prepared to independently provide emergency medical care. The aim of the research is to evaluate nurses ' independence when providing emergency medical care during critical conditions. In order to achieve this goal, anonymous interrogatory was carried out online. The research involved nurses from emergency medical care department and ambulance. The research revealed nurses" readiness to independently provide medical emergency care according to MN28:2019 competencies, most often nurses are independently are able to assign and give patient necessary amount of oxygen, provide emergency care in the case of trauma and injuries, evaluate vital functions, except consiousness according to Glasgow Coma Scale, and perform initial resuscitation. Nurses are least prepared to make decisions in the case of fever occured due to sepsis.More than a tenth of nurses are not able to work with syringe pumps and drop dispensers. Based on research data, assumptions can be made that the biggest part of nurses are prepared to independently assign painkillers such as ibuprofen and paracetamol, also the cardiovascular drug captopril, respiratory inhaler salbutamol as well as oxygen. Also, based on research data, an assumption can be made that nurses are least prepared to independently assign suxamethonium chloride and nifedipine.

Correspondence to: dale.smaidziuniene@go.kauko.lt

Gauta 2021-10-26 